\title{
Movements of a juvenile Crowned Eagle (Harpyhaliaetus coronatus) tracked by satellite telemetry in central Argentina
}

\author{
Vicente Urios ${ }^{1 *}$, Maria Pilar Donat-Torres ${ }^{2}$, Mark Bechard ${ }^{3}$ and Miguel Ferrer ${ }^{4}$
}

\begin{abstract}
Background: A juvenile Crowned Eagle was tagged at its nest with a satellite transmitter. The Crowned Eagle (Harpyhaliaetus coronatus) is one of the most unknown raptor species from the American continent. Their current distribution ranges from central Brazil to central Argentina, with a total population of 350-1500 individuals across this large area, being thus largely fragmented.

Results: During the three years of tracking the bird concentrated its movements in a range spanning for $12845 \mathrm{~km}^{2}$, but concentrating mainly in four smaller areas accounting for $3073 \mathrm{~km}^{2}$. The locations were recorded mainly over shrubland habitats (86.5\%), whereas other habitats used were different types of mosaics that included cropland and natural vegetation (forest, shrubland or grassland) close to wetlands.

Conclusions: The home-range estimated for this individual during the whole period was $12845 \mathrm{~km}^{2}$ (according to 95\% fixed kernel). However, the bird concentrated most of its movements in smaller areas (as defined above), that accounted for a total of $3073 \mathrm{~km}^{2}$ (50\% fixed kernel). During these three years, most of the locations of the juvenile solitary Crowned Eagle were recorded over shrubland habitats (86.5\% of the locations). Understanding in a more detailed way the juvenile ranging behaviour and habitat preferences would be of great importance for the conservation of the Crowned Eagle.
\end{abstract}

Keywords: Conservation, Dispersal, Raptors, GIS

\section{Background}

Juvenile dispersal represents the movements undertaken by juvenile animals to find a breeding site, once they become independent from their parents [1]. In large raptors, this period is one of the most unknown stages in their life (e.g. [2]), mainly due to the difficulty in tracking the movements of dispersing birds [3]. This is especially difficult in non-philopatric species, as absence of proper monitoring schemes prevents to get proper data on this, particularly when observational data is used [4]. Nevertheless, the fate of juvenile birds during this period may have important consequences for population dynamics and thus, it is of particular importance from a conservation point of view [5-8]. The Crowned Eagle (Harpyhaliaetus coronatus) is one of the most unknown raptor species from

\footnotetext{
* Correspondence: vicenteurios@yahoo.es

'Estación Biológica Terra Natura, Universidad de Alicante, Alicante E-03080, Spain

Full list of author information is available at the end of the article
}

the American continent $[9,10]$. Their current distribution ranges from central Brazil to central Argentina, with a total population of 350-1500 individuals across this large area, being thus largely fragmented [10]. Main threats for the species are habitat destruction (e.g. intensive cattle ranching, forest clearance or invasive grasslands) and direct persecution, especially hunting [10-13]. Although population trends are difficult to detect in such low density populations, and given the severity of threats, it seems likely that a significant population decrease is occurring across the whole species' distribution range. For this reason, the Crowned Eagle is currently globally listed as Endangered Species [10]. In Argentina, most of the records of the species belong to the "Monte" ecoregion [12]. The majority of the observations corresponded to solitary individuals and pairs but also groups of up to three individuals composed of two adults and one year-old juvenile have been observed $[14,15]$. Bellocq et al. [16] indicated that habitat preferences for the species are mainly determined by the 
availability of tall isolated trees, which are used for nesting and also as roosts. However, movements of individuals during the juvenile dispersal period of the species are largely unknown.

This species share the same habitat with other resident raptors, especially the Crested Caracara (Plyborus plancus), but also the Chimango Caracara (Milvago chimango), the Peregrine Falcon (Falco peregrinus), the Spot-winged falconet (Spiziapteryx circumcinctus) and the Aplomado Falcon (Falco femoralis). Among scavengers using this habitat we can find the Turkey Vulture (Cathartes aura) and the American Black Vulture (Coragyps atratus). Within the family Accipitridae, the present species are the Cinereous Harrier (Circus cinereus), the White Tailed Hawk (Buteo albicaudatus), the Rufous Tailed Hawk (Buteo ventralis) and the Red Backed Hawk (Buteo polysoma). These species are joined by the Swainson's Hawk (Buteo swainsoni) during the austral summer, while during the austral winter also the White Tailed Kite (Elanus leucurus), the Long-Winged Harrier (Circus buffoni) and the Savanna Hawk (Buteogallus meridionalis) do occur [9]; therefore the only "true eagle" species included in this raptor community is the Crowned Eagle.

In recent years, satellite telemetry has provided new important insights into the juvenile dispersal ecology and habitat use of poorly-known large raptors, even when few individuals are tracked (e.g. [17-20]). Here, we describe the movements undertaken by a juvenile Crowned Eagle tracked by satellite telemetry for three years since it was tagged at its nest. We also assess the habitats used by this individual during the study period. To our knowledge, these are the first detailed data concerning the juvenile dispersal period of this species, which may be important from a conservation point of view.

\section{Results and discussion}

During the study period, a total of 1315 high-quality locations (as defined in Methods) from the tracked eagle were received (i.e., retained for the analyses). Movements of the eagle during the study period are illustrated in Figure 1. Initially, the bird moved short distances, staying 259 days in the nesting area (until 5th October 2007) and moving in a radius of ca. $7 \mathrm{~km}$ (zone A in Figure 1). Then, it moved to another area located at $c a .50 \mathrm{~km}$ to the northwest of the natal area, where it settled on 12th October 2007 and spent 276 days (until 15th July 2008) and mainly moved in a radius of $15 \mathrm{~km}$ (zone B in Figure 1). From this area, the juvenile eagle still continued moving to the northwest, and settled in a new area located $150 \mathrm{~km}$ away from the previous zone, and it spent there more than a year (383 days, from 22nd July 2008 to 9th August 2009; zone $\mathrm{C}$ in Figure 1). While being in this area, the bird performed the largest exploratory movements of the whole study period, with a maximum distance to the centre of this area of $246 \mathrm{~km}$, but always returning to that area. Finally, the eagle moved to the southeast, spent 14 days on the zone B (between 12th and 26th August 2009), and then moved to a new area located ca. $140 \mathrm{~km}$ to the southeast of the natal area (zone D in Figure 1), where it arrived on 2nd September 2009 and remained there at least until the PTT stopped transmitting on 19th January 2010 (139 days), moving mostly in a radius of $c a .10 \mathrm{~km}$.

Table 1 shows the percentage of locations $(\mathrm{N}=1315)$ recorded within different habitat types used by the tracked juvenile Crowned Eagle during three years and percentages of random points. The comparison with available habitat was significant $\left(\chi^{2}=49.1\right.$, g.l. $=8, p<$ $0.05)$, but this was mainly due to the absence of observed locations from not abundant $(\leq 1 \%)$ habitats (Table 1). A further inspection of locations on Google Earth revealed that these activity areas (according to $50 \%$ and $75 \%$ fixed kernels) were mainly located close to wetlands and small lakes along the Atuel and Salado rivers. Concerning seasonal differences, they were significant $\left(\chi^{2}=67.6\right.$, g.l. $\left.=12, p<0.05\right)$, but mainly because of underrepresented habitats, since shrubland habitats were by far always the most used ones (Table 2).

Despite our results derived from only one tracked individual, it has been followed during its movements for three years and, to the best of our knowledge, it has been the first time that a Crowned Eagle has been tracked by means of satellite telemetry. Moreover this species shows a very low density population where only few hundred pairs are still active [10]. Therefore we believe that our results provide valuable information to promote further studies and conservation actions on this species.

In large raptors with delayed maturity and large homeranges, the process of juvenile dispersal until establishing in a breeding territory could take several years (e.g. $[2,17,20])$. Threats faced by juvenile birds during this period may have important consequences for population dynamics and hence, any action aimed at getting information on this may be important from a conservation point of view. Here, in spite of the restrictions imposed by the small sample size, our results are the first quantitative description of the ranging behaviour of a juvenile Crowned Eagle during the juvenile dispersal stage. Despite that we do not know whether the tracked Crowned Eagle finally bred, the ranging behaviour of the tracked juvenile appears to be similar to those of other large eagles of temperate regions, such as Bonelli's (Aquila fasciata) and Spanish Imperial eagles (Aquila adalberti). Juveniles of these species typically follow a "far-sighted", oriented strategy, restricting their movements to a few temporary settlement areas that are 


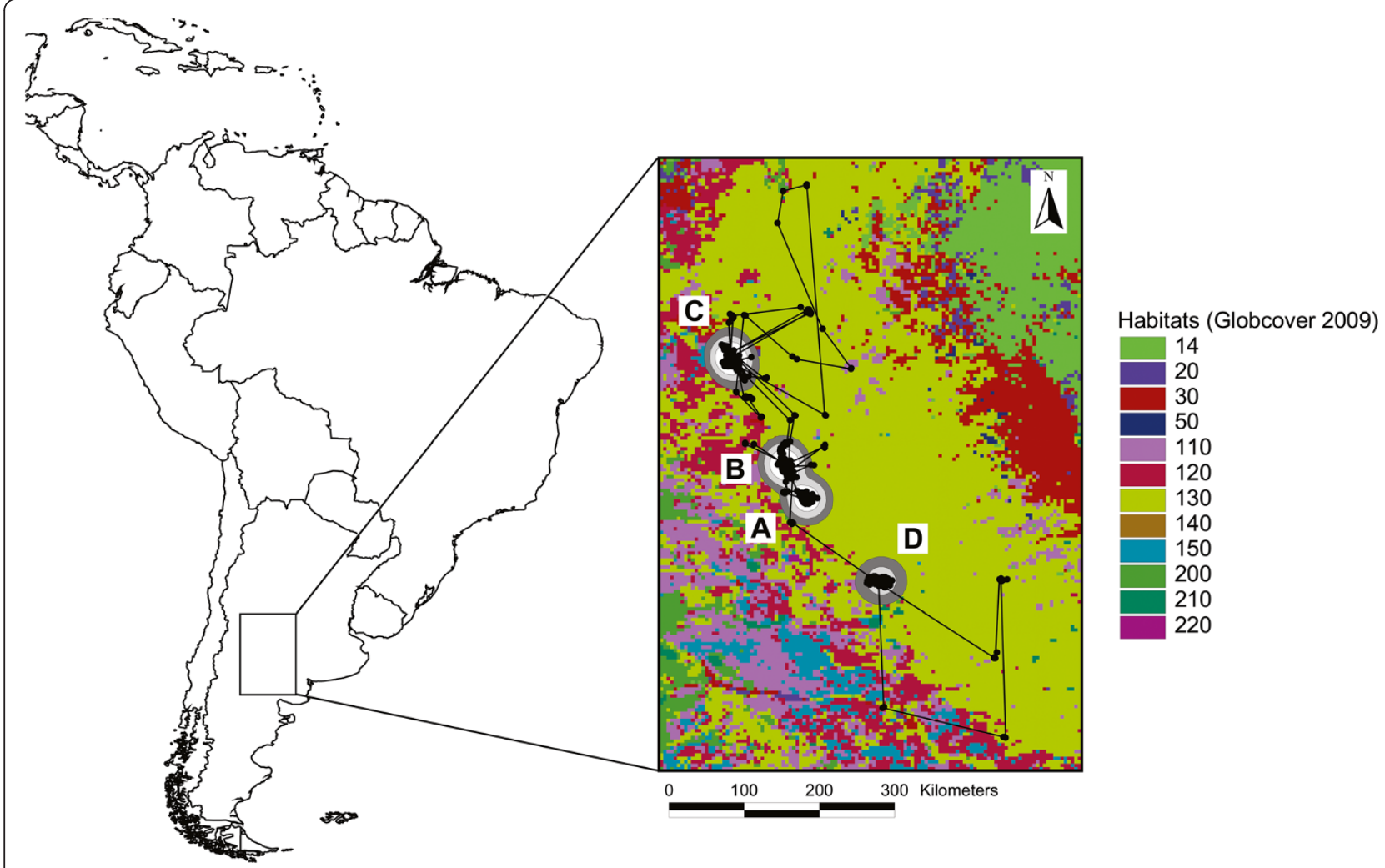

Figure 1 Movements of a satellite tracked juvenile Crowned Eagle in central Argentina. Locations are indicated by black dots and polygons represent fixed kernels (95\%: dark grey, 75\%: light grey and 50\%: white). The eagle was tagged at the nest in zone A, and subsequently moved to zones B, C and D (see text for details). Habitat categories according to GlobCover global land cover map V.2.3 are the following. 14: Rainfed croplands; 20: Mosaic cropland (50-70\%)/vegetation (grassland/shrubland/forest) (20-50\%); 30: Mosaic vegetation (grassland/shrubland/ forest) (50-70\%)/cropland (20-50\%); 110: Mosaic forest or shrubland (50-70\%)/grassland (20-50\%); 120: Mosaic grassland (50-70\%)/forest or shrubland (20-50\%); 130: Closed to open (>15\%) (broadleaved or needleleaved, evergreen or deciduous) shrubland $(<5 \mathrm{~m}) ; 150$ : Sparse (<15\%) vegetation; 200: Bare areas; 210: Water bodies.

Table 1 Percentage of locations and percentages of random points

\begin{tabular}{lll}
\hline Habitat & \% locations & $\begin{array}{l}\text { \% random } \\
\text { points }\end{array}$ \\
\hline $\begin{array}{l}\text { Mosaic vegetation (grassland/shrubland/forest) } \\
\text { (50-70\%)/cropland (20-50\%) }\end{array}$ & 1.2 & 1.1 \\
$\begin{array}{l}\text { Mosaic forest or shrubland (50-70\%)/grassland } \\
\text { (20-50\%) }\end{array}$ & 3.9 & 3.9 \\
$\begin{array}{l}\text { Mosaic grassland (50-70\%)/forest or shrubland } \\
\text { (20-50\%) }\end{array}$ & 6.7 & 5.9 \\
$\begin{array}{l}\text { Closed to open (>15\%) (broadleaved or } \\
\text { needleleaved, evergreen or deciduous) }\end{array}$ & 86.5 & 86.8 \\
shrubland (<5 m) & & \\
$\begin{array}{l}\text { Bare areas } \\
\text { Sparse (<15\%) vegetation }\end{array}$ & 1.7 & 0.4 \\
$\begin{array}{l}\text { Mosaic cropland (50-70\%)/vegetation } \\
\text { (grassland/shrubland/forest) (20-50\%) }\end{array}$ & 0 & 1.0 \\
$\begin{array}{l}\text { Water bodies } \\
\text { Rainfed croplands }\end{array}$ & 0 & 0.3 \\
\hline
\end{tabular}

Percentage of locations $(N=1315)$ recorded within different habitat types used by the tracked juvenile Crowned Eagle during three years and percentages of random points. regularly used for hunting and roosting [19,21-24]. In contrast, other large eagles, such as golden Eagle (Aquila chrysaetos), follow a "blind", un-oriented strategy, continuously increasing the size of their dispersal area, exploring new territories throughout their juvenile dispersal stage $[25,26]$. This un-oriented strategy is

Table 2 Locations within different habitat types

\begin{tabular}{lllll}
\hline Habitat & Summer & Autumn & Winter & Spring \\
\hline $\begin{array}{l}\text { Mosaic vegetation } \\
\text { (grassland/shrubland/forest) }\end{array}$ & 4 & 0 & 12 & 0 \\
$(50-70 \%) /$ cropland (20-50\%) & & & & \\
$\begin{array}{l}\text { Mosaic forest or shrubland } \\
(50-70 \%) / g r a s s l a n d ~(20-50 \%)\end{array}$ & 11 & 11 & 4 & 25 \\
$\begin{array}{l}\text { Mosaic grassland (50-70\%)/forest } \\
\text { or shrubland (20-50\%) }\end{array}$ & 21 & 30 & 13 & 24 \\
$\begin{array}{l}\text { Closed to open (>15\%) } \\
\text { (broadleaved or needleleaved, } \\
\text { evergreen or deciduous) } \\
\text { shrubland (<5 m) }\end{array}$ & 299 & 281 & 288 & 269 \\
\begin{tabular}{l} 
Bare areas \\
\hline
\end{tabular} & 4 & 4 & 1 & 14 \\
\hline
\end{tabular}

Locations recorded within different habitat types used by the tracked juvenile Crowned Eagle according to the season in the austral hemisphere. 
the most demanding in terms of energy requirements [27], and thus can only be employed by animals that can alternatively exploit food resources abundant enough to fulfil individuals' energy requirements. Alternatively, when energy sources are less abundant, an oriented strategy could be more effective in energetic terms $[27,28]$. Given that oriented movements are an efficient strategy for locating suitable foraging habitats [28], the juvenile Crowned Eagle could be restricting its movements to a network of sites that ensure high chances of successful hunting [18,29]. The juvenile eagle tracked here used mostly shrublands during the study period, as well as flooded areas along rivers. This is in agreement with a previous study, where the species was reported to actively use woodlands or isolated trees to rest, which were interspersed in a shrubland matrix [16]. These small forest remnants within larger shrublands are generally used for nesting and therefore, this is also an important habitat for the species from a conservation point of view [16,30]. In fact, the lost of trees for nesting due to the incidence of fires and also due to changes in land use could be affecting the reproduction of this species [12]. On the other hand, the use of wetlands and small lakes is probably related to a higher productivity in those areas compared to that in the surrounding habitats, as it happens with other large raptors in temperate semi-arid areas $[31,32]$. Hence, we show here that other habitats than woodlands used during the nesting period may be important for the species throughout their lifecycle and hence, they need to be considered into conservation schemes for this species. These more-open shrubland habitats could be used by juvenile eagles (as shown here), but may be also important for adult birds during the nesting period [16].

The results of satellite tracking studies are usually limited because of the small sample size associated with the methodology. However, obtaining habitat related information about birds' movements is of great importance from a conservation point of view [33-36], even when few birds are tracked (e.g. $[19,20,37])$. In the case of the Crowned Eagle, further studies involving a higher number of individuals tracked could provide more insights into the juvenile dispersal stage of the species, for example to properly determine the onset of dispersal (e.g. [26,38]), as well as to provide a more detailed understanding of the habitat preferences and requirements of this endangered species. Other interesting questions to be analyzed with conservation concerns could be to evaluate the existence of sexual differences in relation to ranging behaviour and to track individuals of different populations with the aim of estimating the levels of connectivity between subpopulations and thus, to describe the metapopulation structure and dynamics of the highly fragmented population of this species.

\section{Conclusions}

The home-range estimated for this individual during the whole period was $12845 \mathrm{~km}^{2}$ (according to 95\% fixed kernel). However, the bird concentrated most of its movements in smaller areas (as defined in Methods), that accounted for a total of $3073 \mathrm{~km}^{2}$ (50\% fixed kernel). During these three years, most of the locations of the juvenile solitary Crowned Eagle were recorded over shrubland habitats $(86.5 \%$ of the locations), whereas other habitats used were different types of mosaics that included cropland and natural vegetation (forest, shrubland or grassland).

A proper understanding of the juvenile ranging behaviour and habitat preferences would be of great importance for the conservation of the Crowned Eagle.

\section{Methods}

\section{Study area}

The study area covers part of the departments of Chical$\mathrm{Co}$, and Limay Mahuida Chalileo in the province of La Pampa, entering from the north in the province of Mendoza. It belongs to the Monte biogeographic province [39] and geomorphological subregion called "the river floodplains Atuel". The river empties into the Andean Atuel Desagüadero-Salado river forming a floodplain with dunes, plains and sand ridges interspersed with residual plateaus. In general, soils are Entisols. The climate is semi-arid, with average annual temperatures of $15^{\circ} \mathrm{C}$ and rainfall around $300 \mathrm{~mm}$. It is sparsely populated, agricultural and livestock activities being bovine and caprine cattles. The vegetation is characterized by the predominance of open shrublands [40]. The open shrub Larrea divaricata have stood where sand ridges, and other species can codominar: Chuquiraga erinacea, L. divaricata; Prosopis flexuosa. There may be presence of trees and mixed forests formation (Prosopis caldenia) broadleaved or needleleaved in the cooler areas. The shrubland of Atriplex lampa occupies areas peripheral to the salt flats where the salt content is low. The shrubland of Cyclolepis genistoides extends on the periphery of saline areas, forming a ring or belt or semihalófila halophytic vegetation. The halophyte Atriplex undulata scrub supports immersion periods of heavy rainfall. Helophytic vegetation (Typha subulata, Phragmites australis) is installed in permanently flooded areas. Also common psammophile grasslands (Stipa tenuis, Piptochaetium napostaense) transformed by grazing that vary based on usage floristically agriculture.

\section{Field procedures and data analysis}

The juvenile Crowned Eagle was trapped on 19th January 2007 at its nest in central Argentina $\left(-36.708^{\circ}\right.$, $-66.968^{\circ}$; province of La Pampa), when it was $40-50$ days-old. It was tagged with a satellite transmitter (PTT) manufactured by North Star (North Start Science and 
Technology, LLC, King George, VA, USA), which was affixed to their backs using a Teflon harness (e.g. [41]). Duty cycle of the PTT was set to $12 \mathrm{~h} \mathrm{ON} / 48 \mathrm{~h}$ OFF (approximately to collect data for one day every three days). Bird was tracked for three years (until 19th January 2010), when the PTT stopped working for unknown reasons. The juvenile eagle was tracked using the Argos satellite tracking system [42], which estimate locations and calculates an error distribution for each location (i.e. measure of likely accuracy, known as location class -LC-). Nominal high-quality locations (LC 3, 2 and 1) are usually used for analyses that require high degree of accuracy such as those related to habitat use [43], although locations of nominally lower quality ( $0, \mathrm{~A}$ and $\mathrm{B})$ can be used to analyze large-scale movements (such as migrations; e.g. [43-45]). Here we used only locations belonging to LCs 3 to 1 to describe movements in this period as well as for further analyses. Also, when more than one location was received within an hour, we only retained that of higher quality and the others were excluded from the dataset to avoid spatial and temporal autocorrelation (e.g. [41]). We estimated the home-range of the juvenile eagle during the study period using a fixed kernel approach considering all locations received in that period [46]. The 95\%, 75\% and $50 \%$ fixed kernels were calculated using the Animal Movement extension for ArcView 3.2 [47], and using the LSCV procedure [48] to calculate the smoothing parameter $(\mathrm{H})$. The actual size of each kernel polygon was calculated after projecting the shapes into an Equal-Area Cylindrical projection of the globe using the Projector! extension for ArcView 3.2. Finally, we assessed habitats used by the juvenile eagle using the GlobCover global land cover map V.2.3 [49], available in a raster format of $300 \mathrm{~m}$ resolution and obtained from satellite images recorded during 2009. We rescaled this map to a 2.5 arc-min pixel size (i.e., $4.5 \times 4.5 \mathrm{~km}$ ) by retaining the main cover (mode of the pixels within) as the descriptor of the new pixels, to account for the accuracy of Argos-based satellite locations (e.g. [43,50]). We assigned a habitat type to every location recorded during the study period and then calculated the proportions of fixes in every habitat type used. We also compared the observed proportions with expected ones, obtaining habitat availability through 3000 random points within the Minimum Convex Polygon of the observed data [43]. Finally, we checked for seasonal differences comparing the proportions of different habitats across the four seasons. These comparisons were made using Chi-square contingency tables.

\section{Abbreviations}

PTT: Platform Terminal Transmitter; LLC: Limited Liability Company.

\section{Competing interests}

The authors declare that they have no competing interests.

\section{Authors' contributions}

VU conceived of the study, performed the statistical analysis, participated in its design and coordination and drafted the manuscript. MPDT participated in the vegetation study and helped to draft the manuscript. MB conceived of the study and carried out the coordination of study in Argentina. MF conceived and coordinated the study. All authors read and approved the manuscript.

\section{Acknowledgements}

We are indebted to North Star Inc. for donating the satellite transmitter and to J. Sarasola (Universidad Nacional de La Pampa) for placing it on the eagle. The Terra Natura Foundation funded the reception of the satellite data from ARGOS during the three years of the study. We are indebted to Ruben Limiñana (Universidad de Alicante) for helping in the statistical analysis.

\section{Author details}

'Estación Biológica Terra Natura, Universidad de Alicante, Alicante E-03080, Spain. ${ }^{2}$ Instituto de Investigación para la Gestión Integrada de Zonas Costeras IGIC, Universidad Politecnica de Valencia, Gandia E-46730, Spain. ${ }^{3}$ Department of Biology Boise State University, Boise, ID 83725-1515, USA. ${ }^{4}$ Departamento de Etología y Conservación de la Biodiversidad, Estación Biológica de Doñana, Consejo Superior de Investigaciones Científicas CSIC, Sevilla E-41092, Spain.

Received: 30 November 2013 Accepted: 14 March 2014

Published: 1 July 2014

\section{References}

1. Clobert J, Danchin E, Dhont AA, Nichols J: (Eds): Dispersal, Causes, Consequences and Mechanisms of Dispersal at the Individual, Population and Community Level. Oxford: Oxford University Press; 2001.

2. Whitfield DP, Douse A, Evans RJ, Grant J, Love J, McLeod DRA, Reid R, Wilson JD: Natal and breeding dispersal in a reintroduced population of white-tailed eagles Haliaeetus albicilla. Bird Study 2009, 56:177-186.

3. Penteriani V, Delgado MM: Thoughts on natal dispersal. J Raptor Res 2009, 43:90-98.

4. Limiñana R, García JT, González JM, Guerrero Á, Lavedán J, Moreno JD, Román-Muñoz A, Palomares LE, Pinilla A, Ros G, Serrano C, Surroca M, Tena J, Arroyo B: Philopatry and natal dispersal of Montagu's harriers (Circus pygargus) breeding in Spain: a review of existing data. Eur J Wildlife Res 2012, 58:549-555.

5. Whitfield DP, Fielding AH, McLeod DRA, Haworth PF: The effects of persecution on age of breeding and territory occupation in golden eagles in Scotland. Biol Conserv 2004, 118:249-259.

6. Penteriani V, Otalora F, Ferrer M: Floater dynamics can explain positive patterns of density-dependent fecundity in animal populations. Am Nat 2006, 168:697-703.

7. Penteriani V, Ferrer M, Delgado MM: Floater strategies and dynamics in birds, and their importance in conservation biology: towards an understanding of nonbreeders in avian populations. Anim Conserv 2011, 14:233-241.

8. Soutullo A, López-López P, Urios V: Incorporating spatial structure and stochasticity in endangered Bonelli's eagle's population models: implications for conservation and management. Biol Conserv 2008, 141:1013-1020.

9. del Hoyo J, Elliot A, Sargatal J: Handbook of the Birds of the World: Volume 2. Barcelona: Lynx Edicions; 1994.

10. BirdLife International: Crowned Eagle Harpyhaliaetus coronatus. http://www.birdlife.org/datazone/speciesfactsheet.php?id=3496.

11. Sarasola JH, Maceda JJ: Past and current evidence of persecution of the endangered crowned eagle Harpyhaliaetus coronatus in Argentina. Oryx 2006, 40:347-350.

12. Maceda JJ: Biología y conservación del Águila Coronada Harpyhaliaetus coronatus en Argentina. Hornero 2007, 22:159-171.

13. Sarasola JH, Santillán MÁ, Galmes MA: Crowned eagles rarely prey on livestock in central Argentina: persecution is not justified. Endanger Species Res 2010, 11:207-213.

14. Bellocq Ml, Ramírez-Llorens P, Filloy J: Recent records of crowned eagles (Harpyhaliaetus coronatus) from Argentina, 1981-2000. J Raptor Res 2002, 36:206-212. 
15. Di Giacomo AG: Aves de la Reserva El Bagual. In Historia natural y paisaje de la Reserva El Bagual, Provincia de Formosa, Argentina. Inventario de la fauna de vertebrados y de la flora vascular de un área protegida del Chaco Húmedo. Aves Argentinas. Edited by Di Giacomo AG, Krapovickas SF. Buenos Aires: Asociación Ornitológica del Plata; 2005:301-465.

16. Bellocq MI, Bonaventura SM, Marcelino FN, Sabatini M: Habitat use of crowned eagles (Harpyhaliaetus coronatus) in the southern limits of the species' range. J Raptor Res 1998, 32:312-314.

17. Urios V, Soutullo A, López-López P, Cadahía L, Limiñana R, Ferrer M: The first case of successful breeding of a golden eagle Aquila chrysaetos tracked from birth by satellite telemetry. Acta Ornithol 2007, 42:205-209.

18. Soutullo A, Urios V, Ferrer M, López-López P: Habitat use by juvenile golden eagles Aquila chrysaetos in Spain. Bird Study 2008, 55:236-240.

19. Cadahía L, Lopez-Lopez P, Urios V, Negro JJ: Satellite telemetry reveals individual variation in juvenile Bonelli's eagle dispersal areas. Eur J Wildlife Res 2010, 56:923-930.

20. Muñiz-López R, Limiñana R, Cortés GD, Urios V: Movements of harpy eagles Harpia harpyja during their first two years after hatching. Bird Study 2012, 59:509-514.

21. Ferrer M: Juvenile dispersal behaviour and natal philopatry of a long-lived raptor, the Spanish imperial eagle Aquila adalberti. Ibis 1993, 135:132-138.

22. Balbontín J: Identifying suitable habitat for dispersal in Bonelli's eagle: an important issue in halting its decline in Europe. Biol Conserv 2005, 126:74-83.

23. Cadahía L, Urios V, Negro JJ: Survival and movements of satellite-tracked Bonelli's eagles Hieraaetus fasciatus during their first winter. Ibis 2005, 147:415-419.

24. Cadahía L, Urios V, Negro JJ: Bonelli's eagle Hieraaetus fasciatus juvenile dispersal: hourly and daily movements tracked by GPS. Bird Study 2007, 54:271-274

25. Soutullo A, Urios V, Ferrer M, Peñarrubia SG: Post-fledging behaviour in golden eagles Aquila chrysaetos: onset of juvenile dispersal and progressive distancing from the nest. Ibis 2006, 148:307-312.

26. Soutullo A, Urios V, Ferrer M, Peñarrubia SG: Dispersal of golden eagles Aquila chrysaetos during their first year of life. Bird Study 2006, 53:258-264.

27. Vuilleumier S, Perrin N: Effects of cognitive abilities on metapopulation connectivity. Oikos 2006, 113:139-147.

28. Conradt L, Zollner PA, Roper TJ, Frank K, Thomas CD: Foray search: an effective systematic dispersal strategy in fragmented landscapes. Am Nat 2003, 161:905-915.

29. Soutullo A, López-López P, Cortés GD, Urios V, Ferrer M: Exploring juvenile golden eagles' dispersal movements at two different temporal scales. Ethol Ecol Evol 2013, 25:117-128.

30. Bragagnolo L, Maceda JJ, Sarasola J, Reyes M, Salvador V, Santillán M: Caracterización del hábitat de nidificación del Águila Coronada Harpyhaliaetus coronatus en la provincia de La Pampa, Argentina. In II Congreso de Rapaces Neotropicales. Puerto Iguazú, Misiones: Red de Rapaces Neotropicales; 2006:54

31. Bustamante J, Seoane J: Predicting the distribution of four species of raptors (Aves: Accipitridae) in southern Spain: statistical models work better than existing maps. J Biogeogr 2004, 31:295-306.

32. López-Iborra GM, Limiñana R, Pavón D, Martínez-Pérez JE: Modelling the distribution of short-toed eagle (Circaetus gallicus) in semi-arid Mediterranean landscapes: identifying important explanatory variables and their implications for its conservation. Eur J Wildlife Res 2011, 57:83-93.

33. Bakaloudis DE, Vlachos CG: Feeding habits and provisioning rate of breeding short-toed eagles Circaetus gallicus in northeastern Greece. J Biol Res-Thessalon 2011, 16:166-176.

34. Merken R, Servaes F, Sfougaris A, Koedam N: Birds in a complex agricultural landscape in Central Greece: the role of landscape elements and the landscape matrix. J Biol Res-Thessalon 2012, 17:137-147.

35. Tzortzakaki O, Simaiakis S, Xirouchakis S: Abundance of common buzzards (Buteo buteo) in olive monocultures on the island of Crete. J Biol Res-Thessalon 2012, 17:44-50.

36. Panuccio $M$, Chiatante $G$, Tarini $D$ : Two different migration strategies in response to an ecological barrier: Western Marsh Harriers and juvenile European Honey Buzzards crossing the central-eastern Mediterranean in autumn. J Biol Res-Thessalon 2013, 19:10-18.
37. Urios V, López-López P, Limiñana R, Godino A: Ranging behaviour of a juvenile Bearded Vulture (Gypaetus barbatus meridionalis) in South Africa revealed by GPS satellite telemetry. Ornis Fennica 2010, 87:114-118.

38. Cadahía L, López-López P, Urios V, Negro JJ: Estimating the onset of dispersal in endangered Bonelli's eagle Hieraaetus fasciatus tracked by satellite telemetry: a comparison among methods. Ibis 2008, 150:416-420.

39. Cabrera AL: Regiones Fitogeográficas Argentinas. In Enciclopedia Argentina de Agricultura y Jardinería, Tomo 2. Fascículo I. Segunda ediciónth edition. Edited by Ferreira Sobral EF. Buenos Aires: Acme S.A.C.I; 1976.

40. Brouver M, Manghi E, Parmuchi MG, Bono J, Montenegro C, Strada M, Stamati MV: Mapa Forestal Provincia de La pampa. Actualización año 2002. Buenos Aires: Unidad de Manejo del Sistema de Evaluación Forestal UMSEF. Dirección de Bosques, Secretaría de Ambiente y Desarrollo Sustentable. Ministerio de Salud y Ambiente; 2006.

41. Limiñana R, Soutullo A, Urios V: Autumn migration of Montagu's harriers Circus pygargus tracked by satellite telemetry. J Ornithol 2007, 148:517-523.

42. Argos. http://www.argos-system.org.

43. Limiñana $R$, Soutullo A, Arroyo B, Urios V: Protected areas do not fulfil the wintering habitat needs of the trans-Saharan migratory Montagu's harrier. Biol Conserv 2012, 145:62-69.

44. López-López P, Limiñana R, Mellone U, Urios V: From the Mediterranean Sea to Madagascar: are there ecological barriers for the long-distance migrant Eleonora's falcon? Landscape Ecol 2010, 25:803-813.

45. Terraube J, Mougeot F, Cornulier T, Verma A, Gavrilov A, Arroyo B: Broad wintering range and intercontinental migratory divide within a core population of the near-threatened pallid harrier. Divers Distrib 2012, 18:401-409.

46. Worton BJ: Kernel methods for estimating the utilization distribution in home-range studies. Ecology 1989, 70:164-168.

47. Hooge PN, Eichenlaub B: Animal Movement Extension To Arcview Ver. 1.1. Anchorage: Alaska Science Centre-Biological Science Office, US Geological Survey; 1997.

48. Silverman BW: Density Estimation for Statistics and Data Analysis. London: Chapman and Hall; 1986.

49. ESA GlobCover Projec. http://ionia1.esrin.esa.int

50. Jiguet F, Barbet-Massin M, Chevallier D: Predictive distribution models applied to satellite tracks: modelling the western African winter range of European migrant Black Storks Ciconia nigra. J Ornithol 2011, 152:111-118.

doi:10.1186/2241-5793-21-12

Cite this article as: Urios et al:: Movements of a juvenile Crowned Eagle (Harpyhaliaetus coronatus) tracked by satellite telemetry in central Argentina. Journal of Biological Research-Thessaloniki 2014 21:12.

\section{Submit your next manuscript to BioMed Central and take full advantage of:}

- Convenient online submission

- Thorough peer review

- No space constraints or color figure charges

- Immediate publication on acceptance

- Inclusion in PubMed, CAS, Scopus and Google Scholar

- Research which is freely available for redistribution 